\title{
GRAPE POMANCE GENERATION FROM GRAPE CULTIVARS CULTIVATED IN TÂRNAVE VINEYARDS IN THE FRAMEWORK OF THE CLIMATE CHANGE
}

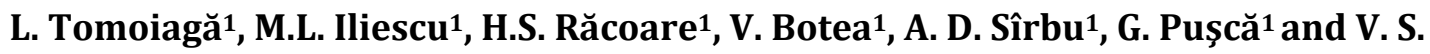 \\ Chedea $^{1 *}$
}

1Research and Development for Viticulture and Enology Blaj (SCDVV Blaj), Romania,

\author{
*Corresponding author e-mail: chedeaveronica@yahoo.com
}

\begin{abstract}
Grape pomace is a by-product obtained from the technological processing of grapes and represents on average $20 \%$ of the total amount of grapes taken for winemaking. Due to the medical, food and cosmetic interest in the valorisation of grape pomace, the present study presents the percentage of pomace resulting, the yield of must and the sugar content of must obtained for $\mathbf{2 5}$ grapevine cultivars, hybrids and clones for white and red wines, cultivated in the SCDVV Blaj vineyards from Blaj, Crăciunelu de Jos and Ciumbrud. In the climatic conditions of the year 2020 with heavy rains in June and cold nights in September, the highest amounts of GP are obtained from the white cultivar Hibernal (GP yield33.43\% and sugar concentration in must $205 \mathrm{~g} / \mathrm{L}$ ) and from the white cultivar Pinot gris 18-5 (GP yield34.09\% and sugar concentration in must $210 \mathrm{~g} / \mathrm{L}$ ). The lowest percentage of GP was obtained in the case of Pinot gris 34 Bl clone, (GP yield18.09\% and sugar concentration in must $236 \mathrm{~g} / \mathrm{L}$ ). Our data show that the harvesting time and the terroir influence the GP yield.
\end{abstract}

Keywords: grape pomace, yield, climat changes, must, Transylvanian grapes

\section{INTRODUCTION}

Grape pomace (GP) is a byproduct generated during the winemaking process and it accounts for approximately $10-30 \%$ of the mass of grapes crushed (Tomaz et al., 2016; Voşloban et al., 2020). GP is constituted of skins, pulp, stalks and seeds, which account to 25-35 kg per $100 \mathrm{~L}$ of produced wine (Mendes et al., 2013). The yield of pomace production varies due to the variability in freshness and moisture contents among the various sources (Muhlack et al., 2017), to the cultivar and terroir, respectively (Voşloban et al., 2020).

GP's generation during the the winemaking process is different for white and red grapes. Thus, seeds and skins are removed before fermentation in white grape winemaking, but not removed only after a maceration period in contact with fermenting must in red grape winemaking (Antoniolli et al., 2015; Tomaz et al., 2016).

Red grapes are entirely involved in fermentation and processed skins contain much less pulp and residual sugars than the skins from white grapes that are mechanically pressed to produce juice and are not subjected to ethanolic fermentation (Silva, 2003; Ruberto et al., 2007; Mendes et al., 2013). Yield is indicator that shows the percentage ratio between the total mass used and the amount of resulting must (Balteş, 2016; Visan et al., 2018), and GP, respectively.The meteorological conditions in which specific grape cultivars are cultivated influence the maturity stage of the grapes and, obviously, the quality of the wine and GP. 
Climate change has left its mark on viticulture in recent years through sudden changes in temperature and heavy rainfall or drought.

Growing grapes is a long-term commitment that requires at least five years before the newly planted vines give high-quality grapes. Changes in weather conditions (an average of 30 years), such as variations in temperature and humidity, late spring frosts, and early autumn frosts, floods, and drought, lead to certain diseases that affect grapes (Iliescu et al., 2019, Irimia et al., 2018).The health benefits of GP polyphenols have been the great interest of researchers, food industry(Beres et al., 2017), cosmetics (Beres et al., 2017; Maluf et al., 2018) and animal nutrition (Beres et al., 2017; Chedea et al., 2019; Chedea et al., 2018). In addition to phenolic antioxidants (Cotea et al., 2018), GPs also contain significant amount of lipids, proteins, nondigestiblefibre and minerals (Yu and Ahmedna, 2012). Due to these interests in GP valorisation this work presents the GP yields for some winegrapescultivars and clones cultivated in Târnave vineyards in the changing climatic conditions of the year 2020.

\section{MATERIALS AND METHODS}

Twenty-five winegrape cultivars: 11 cultivars including 8 white cultivars and 3 red cultivars; 13 clones for white wine, homologated at SCDVV Blaj as well as 1 red hybrid were analysed in this study.

Table 1 presents all the cultivars as well as their harvesting time, vineyard and pressing method.After harvesting the wine grapes were transported to the winemaking unit, were weighted and the berries were taken from the clusters by destemming. In function of the grapes mass's taken for vinification (Table 2) the destemming was done as following: for the mass less than $100 \mathrm{~kg}$ (e.g. Muscat-Ottonel 12 Bl from Crăciunelu de Jos, Syrah, Amurg) the manual crusher/destemmer Marchisio Baby Mano Tram (Italy) was used, for the mass between $101 \mathrm{~kg}-1000$ kg (e.g. Fetească Neagră, Traminer roz-60 Bl, Roze Blaj), the electrical crusher/destemmerGrifo DMC (Italy) was used, and for masses higher than $1001 \mathrm{~kg}$ (Feteasca Regală-21 Bl, Pinot-gris-34 Bl, Riesling Italian-3 Bl), the mechanical-horizontal destemmer /crusher was used. After destemming the resulted clusters were weighted and their percentage from the total grape mass was calculated. The grapes' pressing was done either by small pneumatic (for $90 \mathrm{~kg}$ ), either by big pneumatic presser (for $1100 \mathrm{~kg}$ ) as indicates Table 1.

For the resulting must different parameters were measured: the volume and weight of free run must, the free run must's content in sugar and its density, the volume and weight of the press must, the press must content in sugar, and its density. Sugar content in the must was measured using a refractometerKubler TA 25 no 656/91 (Germany).

In this measurement the unit vol. alc. was used. The density of the must was measured using a densitometer M.D.-A. (Romania) (Voşloban et al., 2020).The mass of total sugar free-run or pressed must $(\mathrm{Kg})$ resulted from multiplication the free-run or pressed must volume with its sugar concentration (free run or pressed must sugar concentration in g/L) (Voşloban et al., 2020).Total sugar (of free-run or pressed must in $\mathrm{kg}$ ) = Volume of the must $\mathrm{x}$ Sugar concentration.

The resulted GP was weighted and its yield was calculated. The percentage of losses was also calculated (Voşloban et al., 2020). Finally the yields for POD wine and table wine was calculated as following: Yield=(Amount of wine or GP/ Amount of grapes)x100. 
Table 1. Studied wine grapecultivars, their harvesting time, vineyard location and pressing method

\begin{tabular}{|c|c|c|c|}
\hline Cultivar/Clone/Hybrid & $\begin{array}{c}\text { Harvesting } \\
\text { data }\end{array}$ & Location & Pressing method \\
\hline \multicolumn{4}{|c|}{ Cultivars } \\
\hline \multicolumn{4}{|c|}{ White cultivars } \\
\hline Blasius & 01.10 .2020 & Crăciunelu de Jos & small pneumatic presser \\
\hline Ezerfurt & 29.10 .2020 & Crăciunelu de Jos & small pneumatic presser \\
\hline Furmint & 29.10 .2020 & Crăciunelu de Jos & small pneumatic presser \\
\hline Hibernal & 07.10 .2020 & Crăciunelu de Jos & small pneumatic presser \\
\hline Radames & 30.09 .2020 & Crăciunelu de Jos & small pneumatic presser \\
\hline RozeBlaj & 01.10 .2020 & Crăciunelu de Jos & small pneumatic presser \\
\hline Rubin & 25.09 .2020 & Crăciunelu de Jos & small pneumatic presser \\
\hline Selena & 25.09 .2020 & Crăciunelu de Jos & small pneumatic presser \\
\hline \multicolumn{4}{|c|}{ Red cultivars } \\
\hline Amurg & 09.10 .2020 & Crăciunelu de Jos & small pneumatic presser \\
\hline Fetească Neagră & 24.09 .2020 & Crăciunelu de Jos & small pneumatic presser \\
\hline Syrah & 09.10 .2020 & Crăciunelu de Jos & small pneumatic presser \\
\hline \multicolumn{4}{|c|}{$\begin{array}{c}\text { Clones } \\
\text { (white cultivars) }\end{array}$} \\
\hline Fetească Albă-29 Bl & $17-19.10 .2020$ & Crăciunelu de Jos & big pneumatic presser \\
\hline Fetească Regală-21 Bl & $\begin{array}{l}30.09- \\
02.10 .2020\end{array}$ & Crăciunelu de Jos & big pneumatic presser \\
\hline Ioardană 9-1 Bl & 01.10 .2020 & Crăciunelu de Jos & small pneumatic presser \\
\hline Muscat Ottonel-12 Bl & $15-16.09 .2020$ & Ciumbrud & big pneumatic presser \\
\hline Muscat Ottonel-12 Bl & 05.10 .2020 & Crăciunelu de Jos & small pneumatic presser \\
\hline Neuburger-10 Bl & 01.10 .2020 & Crăciunelu de Jos & small pneumatic presser \\
\hline Pinot gris 11 Bl & 05.10 .2020 & Blaj & small pneumatic presser \\
\hline Pinot gris 18-5 & 05.10 .2020 & Blaj & small pneumatic presser \\
\hline Pinot gris -34Bl & 16.10 .2020 & Crăciunelu de Jos & big pneumatic presser \\
\hline Riesling italian-3 Bl & 21-22.09.2020 & Ciumbrud & big pneumatic presser \\
\hline Riesling italian-3 Bl & $14-19.10 .2020$ & Crăciunelu de Jos & big pneumatic presser \\
\hline Riesling italian 18-15 & 29.10 .2020 & Blaj & small pneumatic presser \\
\hline Riesling de Rhin 7-2 Bl & 30.09 .2020 & Crăciunelu de Jos & small pneumatic presser \\
\hline Sauvignon blanc-9 Bl & 07-15.10.2020 & Crăciunelu de Jos & big pneumatic presser \\
\hline Traminer roz-60 Bl & $16-17.10 .2020$ & Craciunelu de Jos & big pneumatic presser \\
\hline \multicolumn{4}{|c|}{ Hybrids } \\
\hline \multicolumn{4}{|c|}{ Red cultivar } \\
\hline Regent & 10.09 .2020 & Blaj & small pneumatic presser \\
\hline
\end{tabular}


The experimental data was analyzed with the program Statview 5.0 performing one-way analysis of variance (ANOVA), followed by a Fisher protected least significant difference (PSLD) test. $\mathrm{P}$ values lower than 0.05 were considered significant while $\mathrm{p}$ values between 0.05 and 0.1 were considered as tendencies.

\section{RESULTS AND DISCUSSIONS}

Twenty-five winegrape cultivars: 11cultivars including 8 white cultivars and 3 red cultivars; 13 clones for white wine, homologated at SCDVV Blaj as well as 1 red hybrid were analysed in this study. Most cultivars cultivated in Transylvania, are white cultivars, because these vineyards belong to the B area, according to the UE zoning (Soare et al., 2010. ). Following the technological line of grapes vinification, Table 2 shows the yield of clusters, wich is calculated after crushing-desteamming the grapes.

The desteamming is done by the removal of clusters in order to have a good quality wine and also GP. In our case the percentage of clusters is between 6.1 and 6.7 as Table 2 indicates. The results are in accordance to those presented in the work of Voşloban et al. (2020) also. Thârdea et al. (2010), indicate that the clusters represent 3-8\% of the grape mass and that their chemical composition is close to the one of leaves and tendrils (Ţârdea et al. 2010).

The winemakers choose to make the desteamming because during the vinification process in the clusters take place some osmotic processes as it would be the passage of the clusters' water in mustwhich is hipertonic rich in sugar, and also because during the alcoholic fermentation a part of the formed alcohol is absorbed by the clusters (Ţârdea et al. 2010, Voşloban et al. 2020).

During the crushing-desteamming process the free-run must is collected from which after fermentation the high quality POD wine is obtained. The crushed and desteammed matrix after collecting the free-run must is further pressed- in our case either with a small pneumatic presser, either with a big pneumatic presser in function of the pressed quantity (Table 1)- and the pressing must results. The pressing must is further the base of a lower quality wine like table wine.

For the resulting free-run and pressing must different parameters were measured and calculated (Table 2): volume, mass, sugar concentration, total sugar content and density. In terms of sugar concentration of the free run and pressing must, the limits were between 201.27 g/L for Fetească Regală- 21 Bl, 202.5 g/L for Riesling italian-3Bl, 204.85 g/L for Sauvignon blanc-9Bl and $236 \mathrm{~g} / \mathrm{L}$ for Pinot gris-34 Bl.The results show a wine yield between $54 \%$ and $68 \%$, with the highest value for the cultivars Selena and Furmint, the clones Pinot gris-34 Bl and Fetească Regală-21 Bl (Table 2). The lowest yield (54\%) was determined for the cultivar Hibernal and the clone Pinot gris $18-5$ had also a low yield of $56 \%$. After pressing the matrix resulted after crushing-destemming process, the grape pomace was collected and it was registered a GP yield between $34.09 \%$ for Pinot gris $18-5,33.43 \%$ for Hibernal cultivar and $18.09 \%$ for Pinot gris 34 Bl, 18.56\% for Furmint cultivar.

GP's chemical composition and its generation yield, can vary depending on factors such as environmental conditions, place of origin, grape cultivar, harvest period and various vinification techniques (Bettio, 2008). In this context the climatic conditions influence the production of GP, as they influence the growth and development of the grapes. For instance from our results we can see that the two cultivars of Pinot gris, Pinot gris 18-5 and Pinot gris $34 \mathrm{Bl}$ are situated at extremes concerning the amount of GP generation. The differences might be explained by the fact that they were cultivated in different plantations, Pinot gris 18-5 at Blaj and Pinot gris $34 \mathrm{Bl}$ at Crăciunelu de Jos (Table 1) so we can have a terroir 
influence and that the grapes havesting dates are at a difference of ten days, 05.10.2020 for Pinot gris 18-5 and 16.10.2020 for Pinot gris 34 Bl respectively.

Târnave vineyard classically produces white dry POD wines. In order to check if there is any significant difference between the white cultivars and white clones homologated at SCDVV Blaj and cultivated in Târnave vineyard, in terms of GP production, we performed a statistical analysis.Figure 1 shows that there is no significant difference between these two groups ( $\mathrm{p}=0.5474)$.

Table 2. Technological caracteristics of the studied grape cultivars, clones and hybrids at vinification

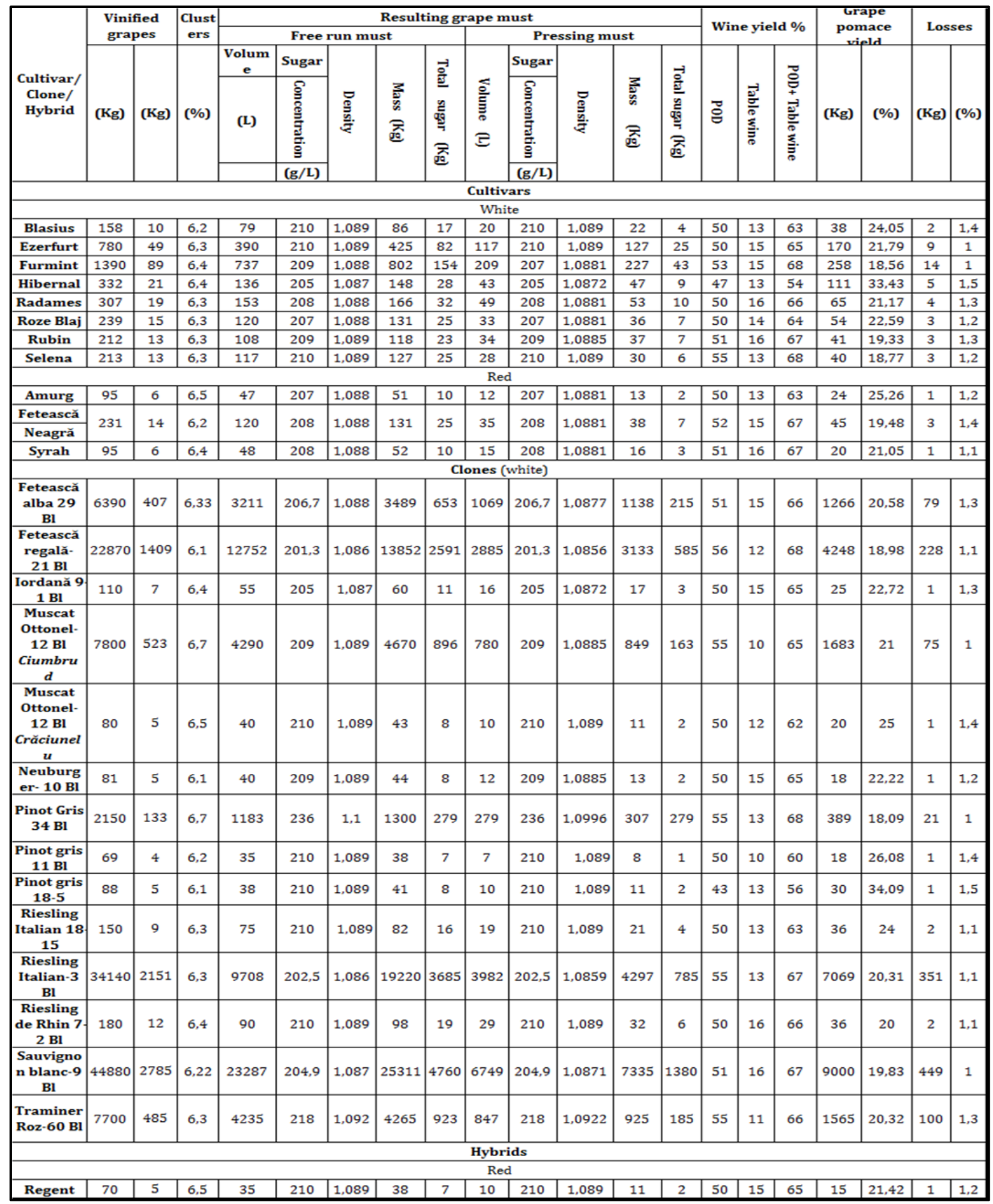




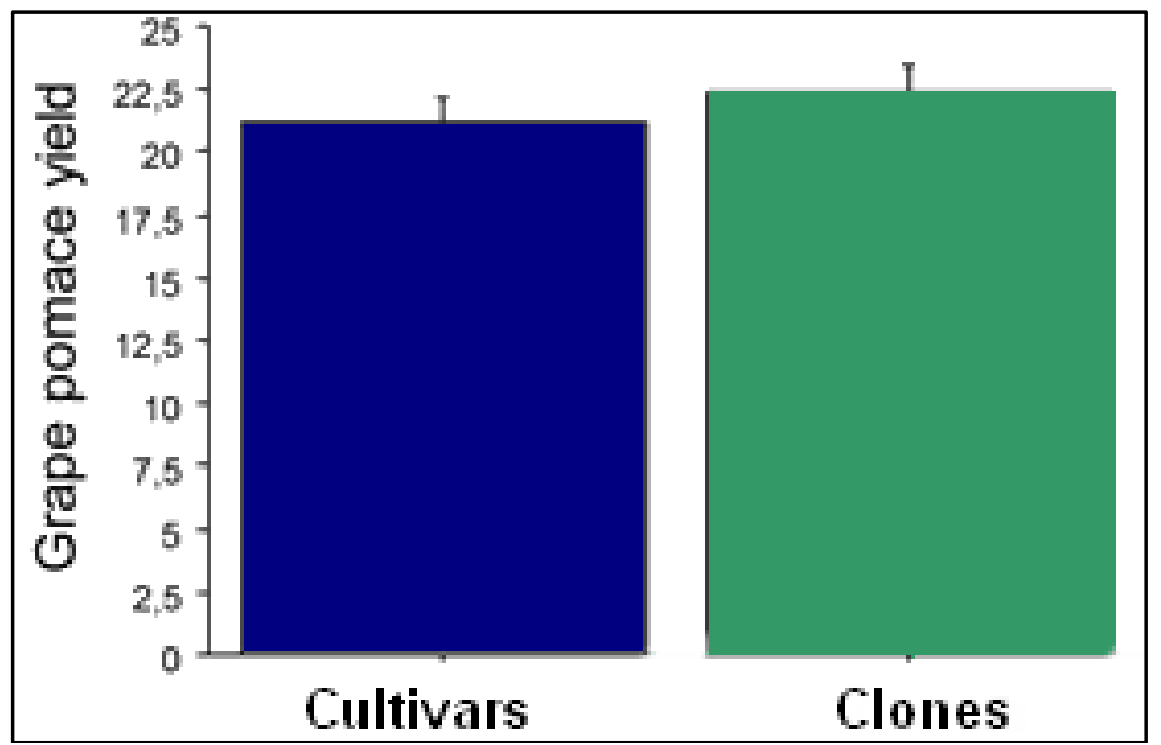

Figure 1. Grape pomace yields for the white cultivars and clones homologated a SCDVV Blaj and cultivated in Târnave vineyard

In the year 2020, the most critical period, climatically, with a negative effect on the plant, was the period of heavy rains in June that delayed the onset of flowering on the vine, and where the plant bloomed there were losses in fruit set.Also, the delay of the flowering period, by about 10 days, created a disturbance of the grapes' veraison. The veraison of grapes was particularly atypical and uneven.The cooling of the nights, in September, had a negative influence on the process of technological maturation of the grapes, with an influence on the sugar/ acidity balance in the must.The values for the active and useful thermal balance, during the vegetation period 2020 are slightly higher than the multiannual value, due to the higher temperatures in March and April. The global thermal balance has lower values until June and exceeds the multiannual average starting with July.

\section{CONCLUSIONS}

In the climatic conditions of the year 2020 with heavy rains in June and cold nights in September, the highest amounts of GP are obtained from the white cultivarHibernal (GP yield $33.43 \%$ and sugar concentration in must $205 \mathrm{~g} / \mathrm{L}$ ) and from the white cultivar Pinot gris 18-5(GP yield34.09\% and sugar concentration in must $210 \mathrm{~g} / \mathrm{L}$ ). Our data show that the harvesting time and the terroir influence the GP yield.

\section{REFERENCES}

1. Antoniolli, A., Fontana, A. R., Piccoli, P. and Bottini, R. (2015). Characterization of polyphenols and evaluation of antioxidant capacity in grape pomace of the cv. Malbec. Food Chemistry. 178:172178. https://doi.org/10.1016/j.foodchem.2015.01.082

2. Balteș, M. V. (2016). Valorificarea subproduselor vinicole cu obținere de produși valoroși pentru industrie și alimentație.Doctoral Thesis. Universitatea Lucian Blaga, Sibiu 
3. Beres C., Costa G. N. S., Cabezudo I., Silva-James N. K. da, Teles A. S. C., Cruz A. P. G., Mellinger-Silva C., Tonon R. V., Cabral L. M. C., and Freitas S. P. (2017). Towards integral utilization of grape pomace from winemaking process: A review. Waste management 68:581594.http://dx.doi.org/10.1016/j.wasman.2017.07.017

4. Bettio, G. (2008). Utilizzo di batteri lattici per la produzione di composti bioattivi a partire da scarti vegetali.Tesi di laurea.Universita degli studi di Padova. Italia

5. Chedea, V. S., Palade, L. M., Marin, D. E., Pelmus, R. S., Habeanu, M., Rotar, M. C., Gras, M. A., Pistol, G. $\mathrm{C}$ and Taranu I. (2018). Intestinal absorbtion and antioxidant activity of grape pomace polyphenols.Nutrients. 10(5):588. https://doi.org/10.3390/nu10050588

6. Chedea, V. S., Palade, L. M., Pelmus, R. S., Dragomir, C., and Taranu, I. (2019). Red grape pomace rich in polyphenols diet increases the antioxidant status in key organs-kidneys, liver, and spleen of piglets. Animals, 9(4):149. https://doi.org/10.3390/ani9040149

7. Corbin, K. R., Hsieh, Y. S., Betts, N. S., Byrt, C. S., Henderson, M., Stork, J.,\& Bourton, R. A. (2015). Grape marc as a source of carbohydrates for bioethanol: Chemical composition, pre-treatment and saccharification. Bioresource Technology, 193:76-83.

8. Cotea, V.V., Luchian, C., Niculaua, M., Zamfir, C.I., Moraru, I., Nechita, B.C. and Colibaba, C. (2018). Evaluation of phenolic compounds content in grape seeds.Environmental Engineering \& Management Journal, 17(4).

9. Iliescu M., Tomoiagă L., Chedea V.S., Pop E.A., Sîrbu A., Popa M., Călugăr A., Babeş A. (2019) Evaluation of climate changes on the vine agrosystem in Tarnave vineyard. Journal of Environmental Protection and Ecology, 20(4): 1754-1760 .

10. Irimia, L.M., Patriche, C.V. and Roșca, B. (2018). Climate change impact on climate suitability for wine production in Romania.Theor Appl Climatol, 133: 1-14.https://doi.org/10.1007/s00704017-2156-z

11. Maluf, D. F., Gonçalves, M. M., Angelo, R. W. O., Girassol, A. B., Tulio, A. P., Pupo Y. M., Paulo V. and Farago P. V. (2018). Cytoprotection of antioxidant biocompounds from grape pomace: further exfoliant phytoactive ingredients for cosmetic products. Cosmetics, 5(3):46. https://doi.org/10.3390/cosmetics5030046

12. Mendes, J. A. S., Xavier A. M. R. B., Evtuguin D. V., and Lopez, L. P. (2013). Integrated utilization of grape skins from white grape pomaces. Industrial crops and products, 49:286-291. https://doi.org/10.1016/j.indcrop.2013.05.003

13. Mildner-Szkudlarz, S., Bajerska, J., Zawirska-Wojtasiak, R., and Górecka, D. (2013). White grape pomace as a source of dietary fibre and polyphenols and its effect on physical and nutraceutical characteristics of wheat biscuits. Journal of the Science of Food and Agriculture, 93(2): 389-395.

14. Muhlack, R. A., Potumarthi, R. \& Jeffery, D. W. (2018). Sustainable wineries through waste valorisation: A review of grape marc utilisation for value-added products. Waste management, 72: 99-118.

15. Okos, M. R., Narsimhan, G., Singh, R. K., Weitnauer, A. C. (1992). Food dehydration in Handbook of food engineering. New York, USA 437 - 562

16. Raghavan, G. S. V., and Orsat, V. (2007). Recent advances in drying of biomaterials for superior quality bioproducts. Asia-Pacific Journal of Chemical Engineering, 2(1):20-29.

17. Ruberto, G., Renda, A., Daquino, C., Amico, V., Spatafora, C., Tringali, C., and De Tommasi, N. (2007). Polyphenol constituents and antioxidant activity of grape pomace extracts from five Sicilian red grape cultivars. Food Chemistry, 100(1):203-210.

18. Silva, L. M. L. R. (2003).Caracterização dos subprodutos da vinificação. IstitutoPolitécnico de Viseu (28) Repositoriohttp://hdl.handle.net/10400.19/594

19. Soare I., Man, O., Costachie, S., Nedelcu, A., Viticultural potential and wine tourism in Romania (2010). Journal of tourism, 10:68-74,

20. Tomaz, I., Maslov, L., Stupić, D., Preiner, D., Ašperger, D., and Kontić, J. K. (2016). Recovery of flavonoids from grape skins by enzyme-assisted extraction. Separation Science and Technology, 51(2): 255-268. https://doi.org/10.1080/01496395.2015.1085881

21. Țârdea C., Sârbu G. and Țârdea A. (2010). Tratat de Vinificație. A II-A. Iași: Ion Ionescu de la Brad. 40-104 
22. Visan, A. L., Bran, M., Milea, D., Paun, A., and Bogdanof, C. G. (2018). A survey of sustainable wine waste management methods in context of environmental policies and grape marc valorization. International Conference on Competitiveness of Agro-food and Environmental Economy Proceedings, 7:114-121.

23. Voşloban C. M., Tomoiagă L.L, Iliescu M., Puşcă G. and Chedea V.S, (2020). Grape pomace yields from Transylvania cultivated grapes, ISB_INMA_TEH Agricultural and mechanical engineering, 61(2):121-129

24. Yu, J., and Ahmedna, M. (2012). Functional components of grape pomace: their composition, biological properties and potential applications. International Journal of Food Science \& Technology, 48(2): 221-237. doi:10.1111/j.1365-2621.2012.03197.x 